\title{
WestVirginiaUniversity.
}

Department of Economics

Working Paper Series

\section{Creating the Environment for Entrepreneurship through Economic Freedom}

Joshua Hall, Robert Lawson Lawson and Saurav Roychoudhury

Working Paper No. 15-01

This paper can be found at the College of Business and Economics Working Paper Series homepage: 


\title{
Creating the Environment for Entrepreneurship through Economic Freedom
}

\author{
Joshua C. Hall \\ Associate Professor of Economics \\ West Virginia University \\ College of Business and Economics \\ 1601 University Avenue \\ Morgantown, WV 26506-6025 \\ 304-293-7870 \\ joshua.hall@mail.wvu.edu \\ Robert A. Lawson \\ Jerome M. Fullinwider Chair in Economic Freedom \\ William J. O’Neil Center for Global Markets and Freedom \\ Edwin L. Cox School of Business \\ Southern Methodist University \\ P.O. Box 750333 \\ Dallas, Texas 75275 \\ 214-768-1708 \\ rlawson@smu.edu \\ Saurav Roychoudhury \\ Associate Professor of Finance \\ School of Management and Leadership \\ Capital University \\ 1 College and Main \\ Columbus, Ohio 43209 \\ 614-236-7230 \\ sroychou@capital.edu
}

\begin{abstract}
In this paper we argue that the ability of people to freely trade, enter into contracts, and start businesses in a system of private property and the rule of law is crucial for productive entrepreneurship. One measure of how freely individuals can engage in economic activity is the Economic Freedom of the World (EFW) index. After examining the economic policies that harm economic freedom and possibly entrepreneurship, we highlight the correspondence between economic freedom and a number of measures of entrepreneurship. We conclude with some thoughts regarding future research involving economic freedom and entrepreneurship.
\end{abstract}

Keywords: economic freedom; institutions; entrepreneurship; new firm JEL Codes: M13; O50 


\section{Creating the Environment for Entrepreneurship through Economic Freedom}

\section{Introduction}

That entrepreneurship is important for economic progress is hardly a point worth arguing in this day and age. Whether talking about the Kirznerian arbitrager or the Schumpeterian creative destructor, both are seen as vital to the economically efficient use of scarce resources. ${ }^{1}$ What is less understood perhaps, or at least less agreed upon, is how a society might go about fostering an entrepreneurial culture.

One approach is to use direct government action to stimulate entrepreneurial activity. In the United States, one prominent example is the Small Business Administration, which according to its website "has delivered millions of loans, loan guarantees, contracts, counseling sessions and other forms of assistance to small businesses.”2 Another approach is to eliminate the multitude of government-imposed impediments to entrepreneurship, and allow the market process to run its course. In other words, entrepreneurship can be fostered through economic freedom.

Consider as an example the Kirznerian entrepreneur who recognizes that bananas sell for $\$ 0.50$ per bunch in Guatemala but sell for $\$ 1.00$ per bunch in the United States. So long as the costs associated with shipping, contract negotiating, financing, required profit, etc. are less than $\$ 0.50$, he will be encouraged to import bananas to the United States from Guatemala. The net gains of this action are easy for neo-classical economists to demonstrate with simple supply and demand diagrams. But if the government of the United States enacts a tariff or otherwise impedes the importation of bananas, this value-creating activity may not take place. Indeed according to the World Bank’s Doing Business project it takes 5 days and $\$ 1,315$ to process a standard shipping container into the United States, and this figure omits an tariffs or customs duties. $^{3}$ Tariffs and duties in the United States average about 3.5\% but can be much higher for 
selected goods. The tariff for dairy products averages $19.8 \%$, for beverages $16.3 \%$, for sugar $12.1 \%$ and for clothing $11.4 \%{ }^{4}$ Costs associated with acquiring an import quota for select additional items, such as sugar or Japanese cars, can add up to even more. How many valuecreating imports are discouraged by this array of policies?

Next consider the Schumpeterian innovator who discovers a new product to meet some consumer desire. What are the impediments to starting her new business? In the United States, the World Bank estimates that it takes 6 procedures, 6 days and 1.4\% of a typical person's annual income to start a business. Not too bad by world standards. But in places like India it is much worse: 12 procedures, 29 days, and a whopping 46.8\% of a typical annual income. What if the new business involves constructing a new building? In India, getting construction permits takes 34 procedures, 227 days and 1631\% of average annual income. To get electricity takes 7 procedures, 67 days and 216\% of average annual income. How many would-be Indian entrepreneurs are squelched by such suffocating regulations? ${ }^{5}$

Rather than adding more government policies to stimulate entrepreneurial activity, would not it be prudent to at least consider eliminating the various government policies that stifle such activity in the first place? This paper will proceed to examine the various economic policies that harm economic freedom and potentially harm entrepreneurial activity. In the end, we will demonstrate the correspondence between economic freedom and various measures of entrepreneurship.

II. Economic Freedom and the Entrepreneurial Environment

We argue that economic freedom, the ability of people to freely trade, enter into contracts, and to compete and start businesses within a legal framework of private property and rule of law, 
is critically important in creating an entrepreneurial environment. In order to support this claim empirically, we first need to measure economic freedom. Fortunately, the Economic Freedom of the World (EFW) index (Gwartney, Lawson and Hall, 2014) provides such a measure. ${ }^{6}$

The construction of the index published in Economic Freedom of the World is based on three important methodological principles. First, objective components are always preferred to those that involve surveys or value judgments. Given the multi-dimensional nature of economic freedom and the importance of legal and regulatory elements it is sometimes necessary to use data based on surveys, expert panels, and generic case studies. To the fullest extent possible, however, the index uses objective components. Second, the data used to construct the index ratings are from external sources such as the International Monetary Fund, World Bank, and World Economic Forum that provide data for a large number of countries. Data provided directly from a source within a country are rarely used, and only when the data are unavailable from international sources. Importantly, the value judgments of the authors or others in the Economic Freedom Network are never used to alter the raw data or the rating of any country. Third, transparency is present throughout. The report provides information about the data sources, the methodology used to transform raw data into component ratings, and how the component ratings are used to construct both the area and summary ratings.

Exhibit 1 indicates the structure of the EFW index. The index measures the degree of economic freedom present in five major areas: (1) Size of Government: Expenditures, and Taxes, Enterprises; (2) Legal Structure and Security of Property Rights; (3) Access to Sound Money; (4) Freedom to Trade Internationally; (5) Regulation of Credit, Labor, and Business.

Within the five major areas, there are 23 components in the index. Many of those components are themselves made up of several sub-components. In total, the index comprises 42 distinct variables. Each component and sub-component is placed on a scale from 0 to 10 . The 
sub-component ratings are averaged to determine each component. The component ratings within each area are then averaged to derive ratings for each of the five areas. In turn, the five area ratings are averaged to derive the summary rating for each country.

\section{$\underline{\text { Size of Government: Expenditures, Taxes, and Enterprises }}$}

The four components of Area 1 indicate the extent to which countries rely on the political process to allocate resources and goods and services. When government spending increases relative to spending by individuals, households, and businesses, government decision-making is substituted for personal choice and economic freedom is reduced. The first two components address this issue. Government consumption as a share of total consumption $(1 \mathrm{~A})$ and transfers and subsidies as a share of GDP (1B) are indicators of the size of government. When government consumption is a larger share of the total, political choice is substituted for personal choice. Similarly, when governments tax some people in order to provide transfers to others, they reduce the freedom of individuals to keep what they earn.

The third component (1C) in this area measures the extent to which countries use private rather than government enterprises to produce goods and services. Government firms play by rules that are different from those to which private enterprises are subject. They are not dependent on consumers for their revenue or on investors for capital. They often operate in protected markets. Thus, economic freedom is reduced as government enterprises produce a larger share of total output.

The fourth component (1D) is based on (Di) the top marginal income tax rate and (Dii) the top marginal income and payroll tax rate and the income threshold at which these rates begin to apply. These two sub-components are averaged to calculate the top marginal tax rate (1D). High marginal tax rates that apply at relatively low income levels are also indicative of reliance upon government. Such rates deny individuals the fruits of their labor. Thus, countries with high 
marginal tax rates and low income thresholds are rated lower.

Taken together, the four components of Area 1 measure the degree to which a country relies on personal choice and markets rather than government budgets and political decision-making. Therefore, countries with low levels of government spending as a share of the total, a smaller government enterprise sector, and lower marginal tax rates earn the highest ratings in this area.

\section{Legal Structure and Security of Property Rights}

Protection of persons and their rightfully acquired property is a central element of economic freedom and a civil society. Indeed, it is the most important function of government. Area 2 focuses on this issue. The key ingredients of a legal system consistent with economic freedom are rule of law, security of property rights, an independent judiciary, and an impartial court system. Components indicating how well the protective function of government is performed were assembled from three primary sources: the International Country Risk Guide, the Global Competitiveness Report, and the World Bank’s Doing Business project.

Security of property rights, protected by the rule of law, provides the foundation for both economic freedom and the efficient operation of markets. Freedom to exchange, for example, is meaningless if individuals do not have secure rights to property, including the fruits of their labor. When individuals and businesses lack confidence that contracts will be enforced and the fruits of their productive efforts protected, their incentive to engage in productive activity is eroded. Perhaps more than any other area, this area is essential for the efficient allocation of resources. Countries with major deficiencies in this area are unlikely to prosper regardless of their policies in the other four areas.

\section{Access to Sound Money}

Money oils the wheels of exchange. An absence of sound money undermines gains from trade. As Milton Friedman informed us long ago, inflation is a monetary phenomenon, caused by 
too much money chasing too few goods. High rates of monetary growth invariably lead to inflation. Similarly, when the rate of inflation increases, it also tends to become more volatile. High and volatile rates of inflation distort relative prices, alter the fundamental terms of longterm contracts, and make it virtually impossible for individuals and businesses to plan sensibly for the future. Sound money is essential to protect property rights and, thus, economic freedom. Inflation erodes the value of property held in monetary instruments. When governments finance their expenditures by creating money, in effect, they are expropriating the property and violating the economic freedom of their citizens.

The important thing is that individuals have access to sound money: who provides it makes little difference. Thus, in addition to data on a country's inflation and its government's monetary policy, it is important to consider how difficult it is to use alternative, more credible, currencies. If bankers can offer saving and checking accounts in other currencies or if citizens can open foreign bank accounts, then access to sound money is increased and economic freedom expanded.

There are four components to the EFW index in Area 3. All of them are objective and relatively easy to obtain and all have been included in the earlier editions of the index. The first three are designed to measure the consistency of monetary policy (or institutions) with long-term price stability. Component 3D is designed to measure the ease with which other currencies can be used via domestic and foreign bank accounts. In order to earn a high rating in this area, a country must follow policies and adopt institutions that lead to low (and stable) rates of inflation and avoid regulations that limit the ability to use alternative currencies.

Freedom to Trade Internationally

In our modern world of high technology and low costs for communication and transportation, freedom of exchange across national boundaries is a key ingredient of economic freedom. Many 
goods and services are now either produced abroad or contain resources supplied from abroad. Voluntary exchange is a positive-sum activity: both trading partners gain and the pursuit of the gain provides the motivation for the exchange. Thus, freedom to trade internationally also contributes substantially to our modern living standards.

In response to protectionist critics and special-interest politics, virtually all countries adopt trade restrictions of various types. Tariffs and quotas are obvious examples of roadblocks that limit international trade. Because they reduce the convertibility of currencies, controls on the exchange rate also hinder international trade. The volume of trade is also reduced if the passage of goods through customs is onerous and time consuming. Sometimes these delays are the result of administrative inefficiency while in other instances they reflect the actions of corrupt officials seeking to extract bribes. In both cases, economic freedom is reduced.

The components in this area are designed to measure a wide variety of restraints that affect international exchange: tariffs, quotas, hidden administrative restraints, and exchange rate and capital controls. In order to get a high rating in this area, a country must have low tariffs, a trade sector larger than expected, easy clearance and efficient administration of customs, a freely convertible currency, and few controls on the movement of capital.

$\underline{\text { Regulation of Credit, Labor, and Business }}$

When regulations restrict entry into markets and interfere with the freedom to engage in voluntary exchange, they reduce economic freedom. The fifth area of the index focuses on regulatory restraints that limit the freedom of exchange in credit, labor, and product markets. The first component (5A) reflects conditions in the domestic credit market. The first two subcomponents provide evidence on the extent to which the banking industry is dominated by private firms and whether foreign banks are permitted to compete in the market. The final two sub-components indicate the extent to which credit is supplied to the private sector and whether 
controls on interest rates interfere with the market in credit. Countries that use a private banking system to allocate credit to private parties and refrain from controlling interest rates receive higher ratings for this regulatory component.

Many types of labor-market regulations infringe on the economic freedom of employees and employers. Among the more prominent are minimum wages, dismissal regulations, centralized wage setting, extension of union contracts to nonparticipating parties, and conscription. The labormarket component (5B) is designed to measure the extent to which these restraints upon economic freedom are present. In order to earn high marks in the component rating regulation of the labor market, a country must allow market forces to determine wages and establish the conditions of hiring and firing, and refrain from the use of conscription.

Like the regulation of credit and labor markets, the regulation of business activities (component 5C) inhibits economic freedom. The sub-components of 5C are designed to identify the extent to which regulations and bureaucratic procedures restrain entry and reduce competition. In order to score high in this portion of the index, countries must allow markets to determine prices and refrain from regulatory activities that retard entry into business and increase the cost of producing products. They also must refrain from “playing favorites," that is, from using their power to extract financial payments and reward some businesses at the expense of others.

III. Economic Freedom and Entrepreneurship

Exhibit 2 presents summary economic freedom ratings, sorted from highest to lowest for 141 countries. These ratings are for the year 2009. Hong Kong and Singapore, once again, occupy the top two positions. The other nations in the top 10 are New Zealand, Switzerland, Australia, Canada, Chile, United Kingdom, Mauritius, and the United States. The rankings of other major countries include Germany $\left(21^{\text {st }}\right)$, Japan $\left(22^{\text {nd }}\right)$, Korea $\left(30^{\text {th }}\right)$, France $\left(42^{\text {nd }}\right)$, Spain $\left(54^{\text {th }}\right)$, Italy 
$\left(70^{\text {th }}\right)$, Mexico $\left(75^{\text {th }}\right)$, Russia $\left(81^{\text {st }}\right)$, China $\left(92^{\text {nd }}\right)$, India $\left(94^{\text {th }}\right)$, and Brazil $\left(102^{\text {nd }}\right)$. The ten lowestrated countries are Chad, Burundi, Republic of Congo, Guinea-Bissau, Central African Republic, Democratic Republic of Congo, Angola, Venezuela, Myanmar, and again in last place, Zimbabwe.

This chapter concludes with some graphs (Exhibits 3-8) illustrating simple relationships between economic freedom and various measures of entrepreneurial activity. The graphs use the average of the EFW index for the period from 1990 to 2010, breaking the data into four quartiles ordered from low to high. Because persistence is important and the impact of economic freedom will be felt over a lengthy time period, it is better to use the average rating over a fairly long time span rather than the current rating to observe the impact of economic freedom on performance.

We are not necessarily arguing that there is a direct causal relation between economic freedom and the variables considered below. In other words, these graphics are no substitute for real, scholarly investigation that controls for other factors. Nonetheless, we believe that the graphs provide some insights about the contrast between the nature and characteristics of marketoriented economies and those dominated by government regulation and planning. At the very least, these figures suggest potential fruitful areas for research, which we will highlight while discussing the exhibits. ${ }^{7}$

Nevertheless, each and every indicator we have examined related to entrepreneurship demonstrates the positive relationship between economic freedom and entrepreneurial activity. Exhibit 3, for example, looks at the relationship between economic freedom and new firm entry density, which is defined as the number of newly registered limited liability firms per 1,000 working age people. The exhibit shows that new firm entry density is more than three times higher in the most economically free quartile of countries compared to the least economically free quartile. Interestingly, new firm entry density actually declines when going from the least 
free quartile to the next quartile.

Given the aggregate nature of this data it is difficult to pinpoint exactly why this non-linear relationship between economic freedom and new firm entry density might exist but one possibility might be related to how the incentives for formalization of new businesses change while economic freedom is increasing. For example, in countries where government plays a very direct role in planning economic activity, the formal registration of favored businesses is relatively straightforward and simple. Then when countries move away from outright planning but fail to provide widespread economic freedom, the incentives for formalization of new firms drops until economic freedoms across a number of areas can be secured, as is evidenced by the increase in new firm entry density going from the second highest quartile to the highest quartile.

Exhibit 4 illustrates the relationship between economic freedom and the Global Entrepreneurship and Development Index (GEDI). The GEDI measures entrepreneurial attitudes, activities, and aspirations across a large number of countries. Like in the case with new firm entry density, there exists a large difference between scores in the least economically free quartile of countries and the most economically free quartile of countries. While average GEDI scores increase for every quartile from the lowest to the highest, it should be noted that the biggest jump occurs from the second freest quartile to the most economically free quartile. A similarly large jump when going from the second to the most economically free quartile can be seen in Exhibit 3. A similar relationship can be seen in Exhibit 5, which shows the relationship between the EFW and the Entrepreneurship and Opportunity sub-index of the Legatum Institute's Legatum Prosperity Index. To be in the most economically free quartile a country generally has to be economically free across all five areas of the EFW index. This suggests that that being economically free across multiple areas of economic freedom might be important to entrepreneurship and consequently to economic progress. Future research is needed on how 
exactly the various components of economic freedom work together to foster entrepreneurship.

In a manner similar to the three previous exhibits, Exhibits 6, 7, and 8 employ survey questions from the World Economic Forum's Executive Opinion Survey that are related to entrepreneurship. For example, Exhibit 6 uses responses to the question "How easy or difficult is it to start a new business in your country?” Countries receive scores based on aggregated answers from individuals, who answered the question with a score ranging from 1 (very difficult) to 7 (very easy). The figure again shows a positive relationship between how economically free a country is and this measure of entrepreneurship. It is important to note that this question, unlike new firm entry density in Exhibit 3, does not distinguish between formal and informal enterprises and instead merely reflects survey respondents perceptions of how easy it is to start a business. One possible fruitful area of research suggested by this exhibit is how does economic freedom relate differently, if at all, to entrepreneurial perceptions or motivations compared to entrepreneurial actions.

Economically free countries because economically free societies have higher incomes and more developed banking sectors. This is important for entrepreneurs as it makes available resources to be used in the formation of new enterprises. Exhibits 7 and 8 highlight this point using survey data on access to bank loans and venture capital availability. The results are consistent: in countries with greater economic freedom entrepreneurs have greater access to bank loans and venture capital.

\section{Concluding Thoughts}

Entrepreneurs enhance our lives by directing resources toward their most valuable uses and by creating new products to satisfy our wants and desires. Both economic intuition and the empirical evidence support the notion that societies with more economic freedom foster greater 
entrepreneurial activity. This result is confirmed not only in the simple relationships we have presented here, but also in a growing number of empirical studies (Kreft and Sobel 2005;

Campbell and Rogers 2007; Bjørnskov and Foss 2008; Gohmann et al. 2008; Nyström 2008;

Hall and Sobel 2008; Wiseman and Young 2013; Hall et al. 2013).

Despite this growing literature, there is still much about the relationship between economic freedom and entrepreneurship that it is not well understood. For example, how important are local barriers to entrepreneurship? The Institute for Justice, a special-interest law firm in Washington D.C., has published multiple reports showing the regulatory burdens facing entrepreneurs in U.S. cities (Milnikel and Satterthwaite 2010; Hottot 2010; Bindas 2010; Frommer 2010). These reports not only document the significant local barriers to entrepreneurship that exist within major cities in the United States, they also highlight how cross-country evidence does not necessarily shed light on specific regulations that may impose significant costs upon potential and actual entrepreneurs in a particular industry. While the true costs of regulation might never be known (Benson 2004) they are likely to be large and vary by location and sector. Future research can take advantage of new sources of data like the Economic Freedom Index of Metropolitan Areas (Stansel 2013) and RegData (Al-Ubaydli and McLaughlin 2013).

Little is also known about the distribution of benefits from the opening up of entrepreneurial opportunities that comes from economic freedom. One of the benefits of case studies like the ones from the Institute for Justice and those contained in Llosa (2008) is that they illustrate how the entrepreneurial decisions of the poor are distorted by regulations. The high cost of complying with regulations that enact high barriers to entry into the formal sector mean that the poor either give up their entrepreneurial dreams or pursue their entrepreneurial activity in the informal sector. $^{8}$ 
A final related topic in need of additional research is the difference between entrepreneurship and wealth creation. Presumably the reason why so many policymakers and scholars are concerned with entrepreneurship is because of its contribution to economic progress. Selfemployment, however, could be the result of limitations on economic freedom. For example, low levels of economic freedom could stifle the development of a large formal sector, limiting paid employment opportunities and driving many individuals to self-employment out of necessity. Or the growth of small businesses in a region could reflect rent seeking instead of profit seeking (Sobel and Garrett 2002; Hall and Ross 2009). Two recent papers that focus on how institutions shape entrepreneurial opportunities towards wealth creation are Sobel (2008) and Sanandaji and Leeson (2013) provide a good foundation upon which future research could build. 
Exhibit 1: The Areas and Components of the EFW Index

Area 1: Size of Government: Expenditures, Taxes, and Enterprises
A
B
Transfers and subsidies as a
B percentage of GDP
C investment
D Top marginal tax rate
percentage of total consumption i rate
Top marginal income and
ii payroll tax rates
Top marginal income tax

General government

consumption spending as a

Area 2: Legal Structure and Security of Property Rights
A Judicial independence
B Impartial courts
C Protection of property rights
Military interference in rule of
D law and the political process
E Integrity of the legal system
F Legal enforcement of contracts
Regulatory restrictions on the
$\mathrm{G}$ sale of real property

Area 3: Access to Sound Money
A
B
Money growth
C Inflation: Most recent year
Standard deviation of inflation
D currency bank accounts

\section{Area 4: Freedom to Trade Internationally}

A

i.

ii

iii

B

Taxes on international trade

Revenues for trade taxes

(\%of trade sector)

Mean tariff rate

Standard deviation of tariff

rates

B Regulatory Trade Barriers

i Non-tariff trade barriers

Compliance cost of

ii importing \& exporting 
D

E

Size of the trade sector relative to expected

Black-market exchange rates International capital market controls

$\begin{array}{ll} & \text { Foreign } \\ & \text { ownership/investment } \\ \text { ii } & \text { restrictions } \\ & \text { Capital controls }\end{array}$

Area 5: Regulation of Credit, Labor, and Business

A

Credit market regulations

i.

Ownership of banks

ii

iii

iv

Foreign bank competition

Private sector credit

Interest rate

controls/Negative real

B

interest rates

Labor market regulations

Hiring regulations and

i

minimum wage

Hiring and firing

ii regulations

Centralized collective

iii bargaining

iv Hours regulations

Mandated cost of worker

v dismissal

vi Conscription

C

Business Regulations

i

Price controls

Administrative

ii requirements

iii Bureaucracy costs

iv Starting a business

Extra

$\mathrm{V} \quad$ payments/bribes/favoritism

vi Licensing restrictions

vii Cost of tax compliance 
Exhibit 2: Economic Freedom Ratings and Rankings, 2009

\begin{tabular}{|r|l|r|}
\hline & & $\begin{array}{r}\text { EFW } \\
\text { Index, } \\
\text { Rank }\end{array}$ \\
\hline 1 & Countries & $\mathbf{2 0 0 9}$ \\
\hline 2 & Singapore & 9.01 \\
\hline 3 & New Zealand & 8.68 \\
\hline 4 & Switzerland & 8.20 \\
\hline 5 & Australia & 8.03 \\
\hline 6 & Canada & 7.98 \\
\hline 7 & Chile & 7.81 \\
\hline 8 & United Kingdom & 7.77 \\
\hline 9 & Mauritius & 7.71 \\
\hline 10 & United States & 7.67 \\
\hline 11 & Bahrain & 7.60 \\
\hline 11 & Finland & 7.59 \\
\hline 13 & Slovak Rep & 7.59 \\
\hline 14 & Unit. Arab Em. & 7.56 \\
\hline 15 & Denmark & 7.54 \\
\hline 15 & Estonia & 7.52 \\
\hline 15 & Hungary & 7.52 \\
\hline 18 & Cyprus & 7.52 \\
\hline 19 & Austria & 7.51 \\
\hline 20 & Luxembourg & 7.50 \\
\hline 21 & Germany & 7.49 \\
\hline 22 & Japan & 7.45 \\
\hline 23 & Panama & 7.44 \\
\hline 24 & Lithuania & 7.41 \\
\hline 25 & Ireland & 7.40 \\
\hline 26 & Taiwan & 7.38 \\
\hline 27 & Georgia & 7.37 \\
\hline 28 & Bulgaria & 7.36 \\
\hline 28 & Oman & 7.34 \\
\hline 30 & Albania & 7.34 \\
\hline 30 & Korea, South & 7.32 \\
\hline 30 & Netherlands & 7.32 \\
\hline 33 & Malta & 7.32 \\
\hline 33 & Peru & 7.31 \\
\hline 35 & Norway & 7.31 \\
\hline 36 & Mongolia & 7.30 \\
\hline 37 & Montenegro & 7.29 \\
\hline 38 & Zambia & 7.27 \\
\hline 39 & Sweden & 7.26 \\
\hline 40 & Bahamas & 7.24 \\
\hline 41 & Costa Rica & 7.17 \\
\hline & & \\
\hline
\end{tabular}




\begin{tabular}{|c|c|c|}
\hline 42 & France & 7.16 \\
\hline 43 & Armenia & 7.15 \\
\hline 43 & Belgium & 7.15 \\
\hline 43 & El Salvador & 7.15 \\
\hline 46 & Czech Rep. & 7.13 \\
\hline 47 & Kuwait & 7.10 \\
\hline 48 & Romania & 7.08 \\
\hline 49 & Guatemala & 7.07 \\
\hline 49 & Jamaica & 7.07 \\
\hline 51 & Honduras & 7.06 \\
\hline 52 & Uganda & 7.01 \\
\hline 53 & Poland & 7.00 \\
\hline 54 & Spain & 6.99 \\
\hline 54 & Trinidad \& Tob. & 6.99 \\
\hline 56 & Kazakhstan & 6.97 \\
\hline 56 & Kenya & 6.97 \\
\hline 58 & Belize & 6.95 \\
\hline 59 & Portugal & 6.93 \\
\hline 60 & Latvia & 6.92 \\
\hline 61 & Pap. New Guinea & 6.91 \\
\hline 62 & Jordan & 6.90 \\
\hline 62 & Uruguay & 6.90 \\
\hline 64 & Macedonia & 6.88 \\
\hline 65 & Thailand & 6.87 \\
\hline 66 & Namibia & 6.86 \\
\hline 67 & Haiti & 6.84 \\
\hline 68 & Botswana & 6.83 \\
\hline 69 & Nicaragua & 6.82 \\
\hline 70 & Ghana & 6.81 \\
\hline 70 & Iceland & 6.81 \\
\hline 70 & Italy & 6.81 \\
\hline 70 & Kyrgyz Republic & 6.81 \\
\hline 74 & Slovenia & 6.78 \\
\hline 75 & Mexico & 6.74 \\
\hline 75 & Turkey & 6.74 \\
\hline 77 & Fiji & 6.71 \\
\hline 78 & Dominican Rep. & 6.68 \\
\hline 78 & Malaysia & 6.68 \\
\hline 80 & Paraguay & 6.57 \\
\hline 81 & Greece & 6.55 \\
\hline 81 & Russia & 6.55 \\
\hline 83 & Israel & 6.53 \\
\hline 84 & Azerbaijan & 6.50 \\
\hline 84 & Barbados & 6.50 \\
\hline 84 & Indonesia & 6.50 \\
\hline 87 & South Africa & 6.49 \\
\hline
\end{tabular}




\begin{tabular}{|c|c|c|}
\hline 88 & Vietnam & 6.48 \\
\hline 89 & Croatia & 6.46 \\
\hline 89 & Philippines & 6.46 \\
\hline 91 & Serbia & 6.44 \\
\hline 92 & China & 6.43 \\
\hline 93 & Egypt & 6.42 \\
\hline 94 & India & 6.40 \\
\hline 94 & Tunisia & 6.40 \\
\hline 96 & Madagascar & 6.29 \\
\hline 96 & Moldova & 6.29 \\
\hline 96 & Rwanda & 6.29 \\
\hline 99 & Bolivia & 6.27 \\
\hline 100 & $\begin{array}{l}\text { Bosnia and } \\
\text { Herzegovina }\end{array}$ & 6.23 \\
\hline 101 & Colombia & 6.21 \\
\hline 102 & Brazil & 6.19 \\
\hline 103 & Bangladesh & 6.17 \\
\hline 103 & Malawi & 6.17 \\
\hline 105 & Iran & 6.16 \\
\hline 105 & Morocco & 6.16 \\
\hline 107 & Nigeria & 6.12 \\
\hline 107 & Sri Lanka & 6.12 \\
\hline 109 & Lesotho & 6.11 \\
\hline 110 & Guyana & 6.10 \\
\hline 111 & Mauritania & 6.05 \\
\hline 112 & Ecuador & 6.04 \\
\hline 112 & Tanzania & 6.04 \\
\hline 114 & Pakistan & 6.03 \\
\hline 115 & Mali & 5.98 \\
\hline 116 & Cameroon & 5.97 \\
\hline 117 & Benin & 5.96 \\
\hline 118 & Burkina Faso & 5.94 \\
\hline 119 & Argentina & 5.90 \\
\hline 120 & Cote d'Ivoire & 5.86 \\
\hline 121 & Syria & 5.83 \\
\hline 122 & Gabon & 5.82 \\
\hline 123 & Togo & 5.74 \\
\hline 124 & Senegal & 5.73 \\
\hline 125 & Ukraine & 5.70 \\
\hline 126 & Ethiopia & 5.62 \\
\hline 126 & Sierra Leone & 5.62 \\
\hline 128 & Mozambique & 5.53 \\
\hline 129 & Nepal & 5.50 \\
\hline 130 & Niger & 5.44 \\
\hline 131 & Algeria & 5.36 \\
\hline 132 & Chad & 5.32 \\
\hline
\end{tabular}




\begin{tabular}{|r|l|r|}
\hline 133 & Burundi & 5.12 \\
\hline 134 & Congo, Rep. Of & 5.04 \\
\hline 135 & Guinea-Bissau & 5.03 \\
\hline 136 & Central Afr. Rep. & 4.88 \\
\hline 137 & Congo, Dem. R. & 4.84 \\
\hline 138 & Angola & 4.76 \\
\hline 139 & Venezuela & 4.28 \\
\hline 140 & Myanmar & 4.16 \\
\hline 141 & Zimbabwe & 4.08 \\
\hline
\end{tabular}




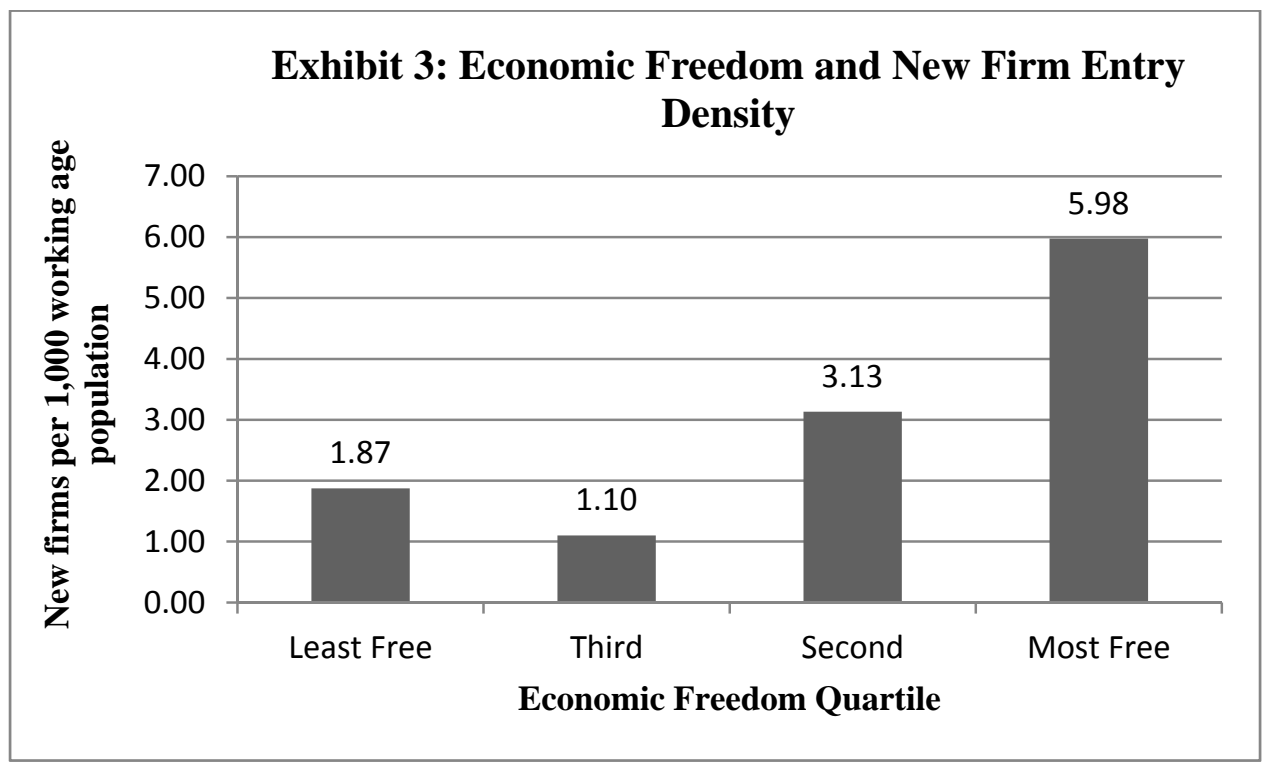

Sources: Fraser Institute, Economic Freedom of the World; World Bank Group Entrepreneurship Snapshots Database, 2010.

Note: New Firm Entry Density: Is the number of newly registered limited liability firms per 1,000 working-age people (those ages 15-64). 


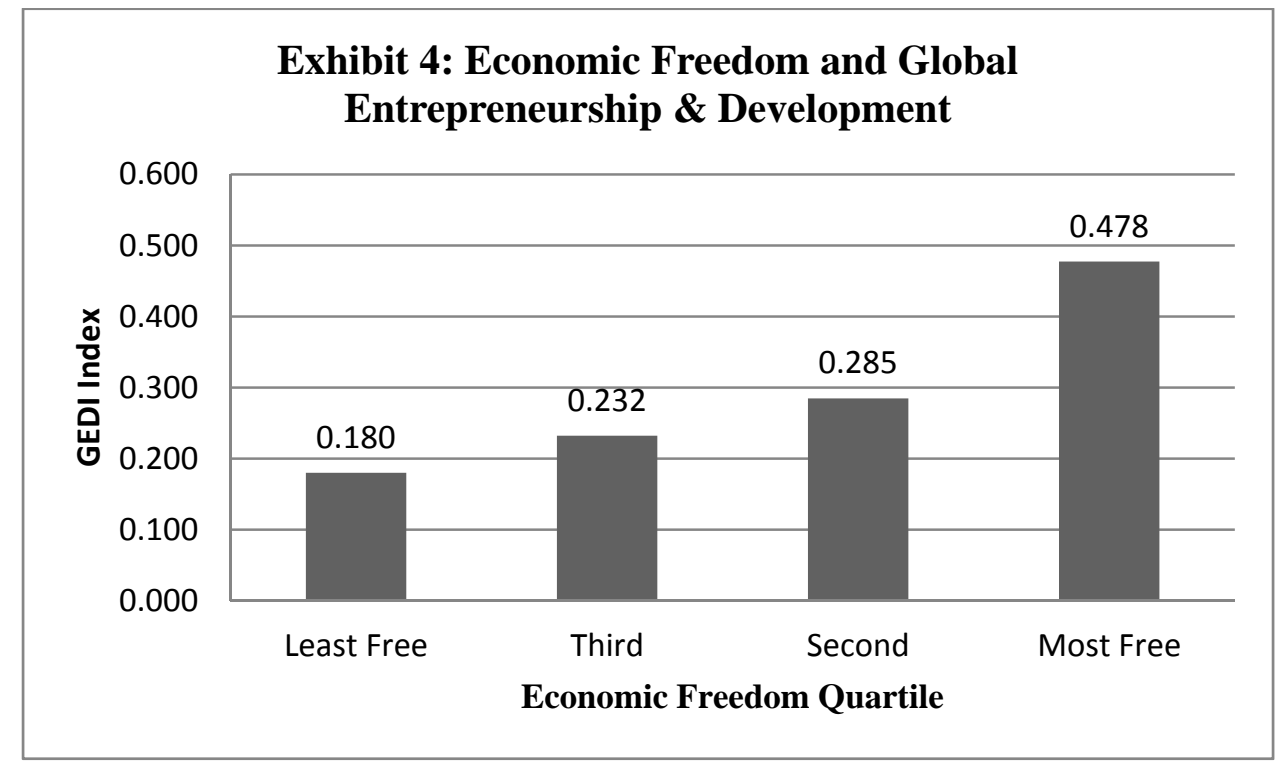

Sources: Fraser Institute, Economic Freedom of the World; Center for Entrepreneurship and Public Policy (CEPP) at George Mason University, Global Entrepreneurship and Development Index (GEDI), 2010.

Note: The Global Entrepreneurship and Development Index (GEDI) comprises of three subindices on Entrepreneurial Attitudes, Entrepreneurial Activities and, Entrepreneurial Aspirations. 


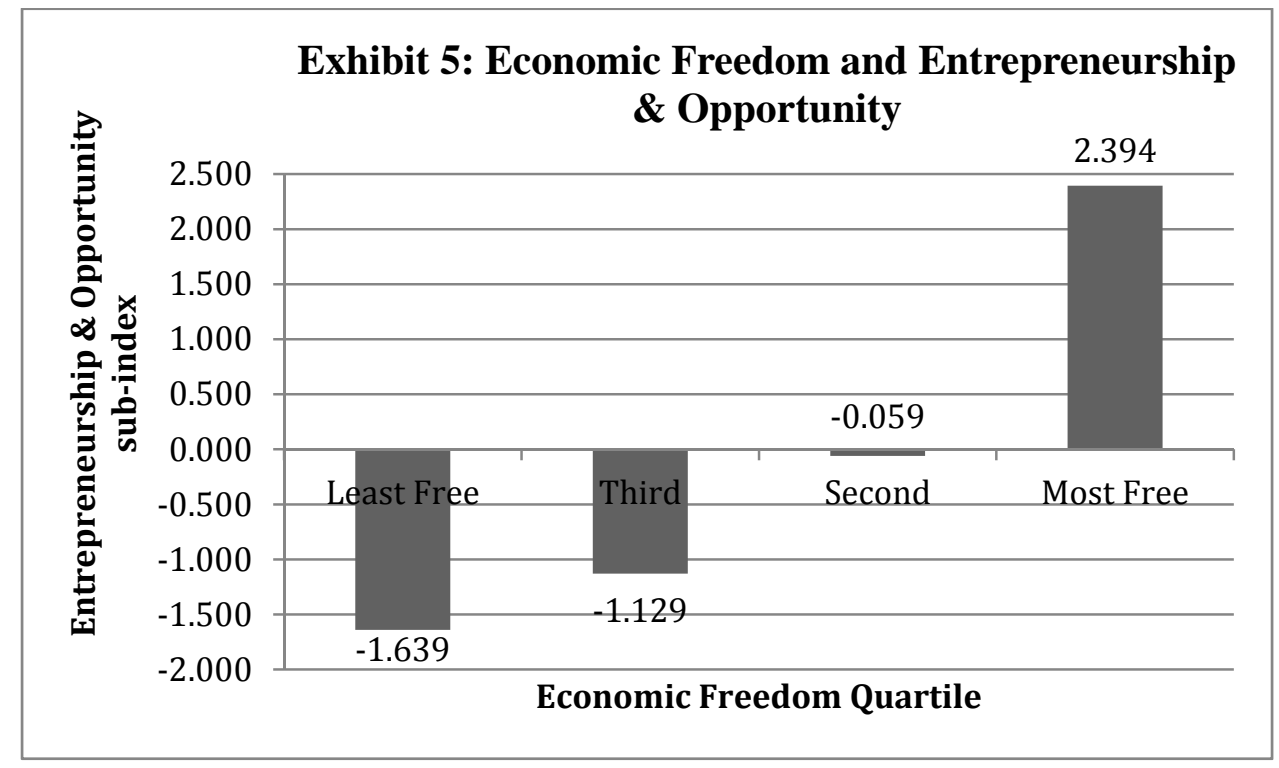

Sources: Fraser Institute, Economic Freedom of the World; Legatum Institute, Legatum Prosperity Index ${ }^{\mathrm{TM}}, 2012$.

Note: The Legatum Prosperity Index ${ }^{\mathrm{TM}}$ is a multidimensional composite index that provides an assessment of prosperity in 110 countries around the world. The Index uses 89 variables, which are statistically related to income and well-being, and categorizes them into eight fundamental pillars of prosperity (sub-indices).The Prosperity Index is the equally weighted average of the eight pillars of prosperity. We use the Entrepreneurship and Opportunity pillar or Sub-Index. The numbers used are simple averages of 2009 and 2010. 


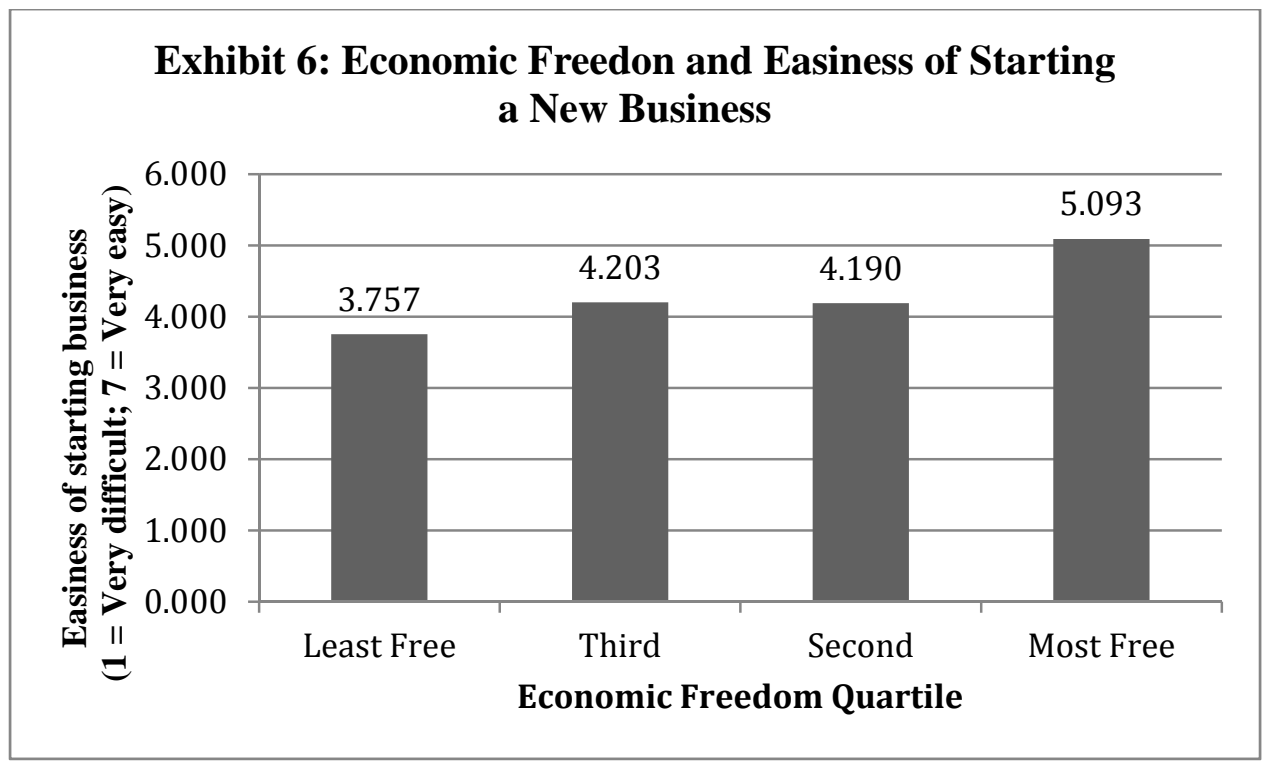

Sources: Fraser Institute, Economic Freedom of the World; World Economic Forum, Executive Opinion Survey.

Note: Based on the question: "How easy or difficult is it to start a new business in your country? (1 = Very difficult; 7 = Very easy)” (Executive Opinion Survey). 


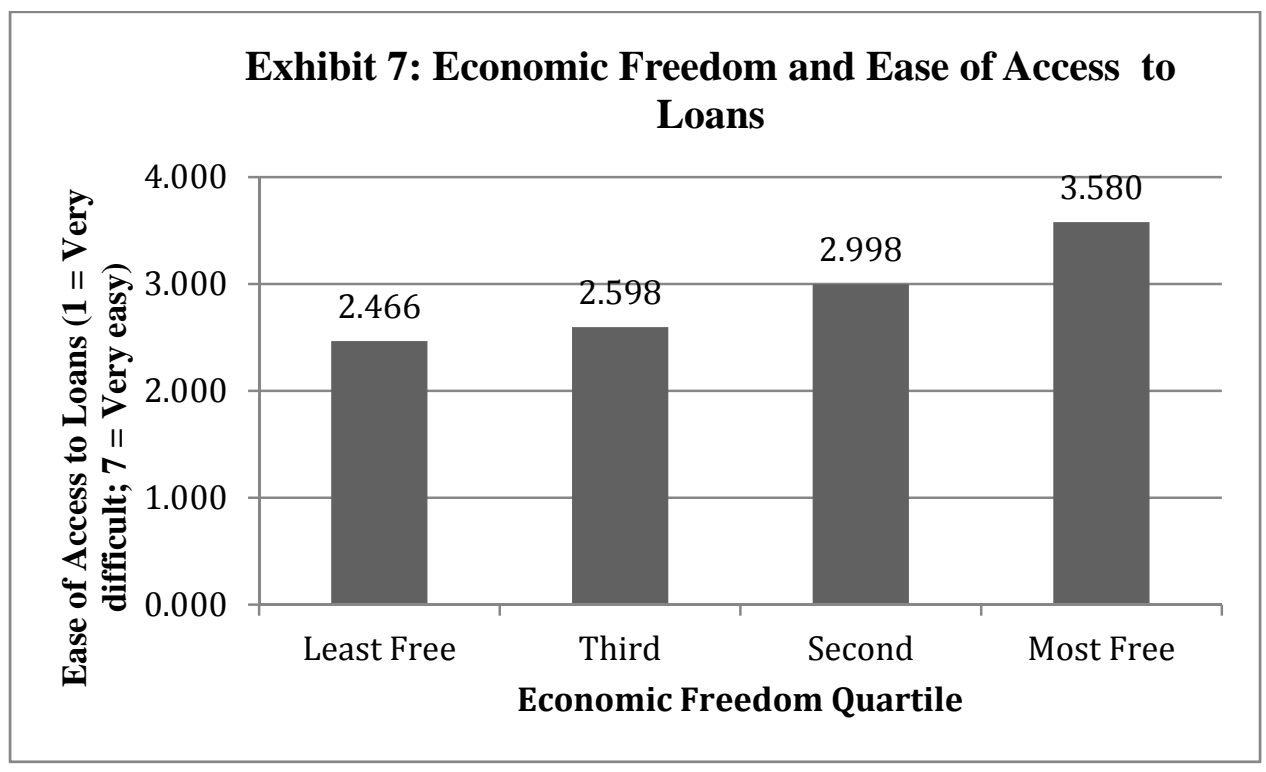

Sources: Fraser Institute, Economic Freedom of the World; World Economic Forum, Executive Opinion Survey.

Note: Based on the question: "How easy is it to obtain a bank loan in your country with only a good business plan and no collateral? (1 = Very difficult; 7 = Very easy)" (Executive Opinion Survey). 


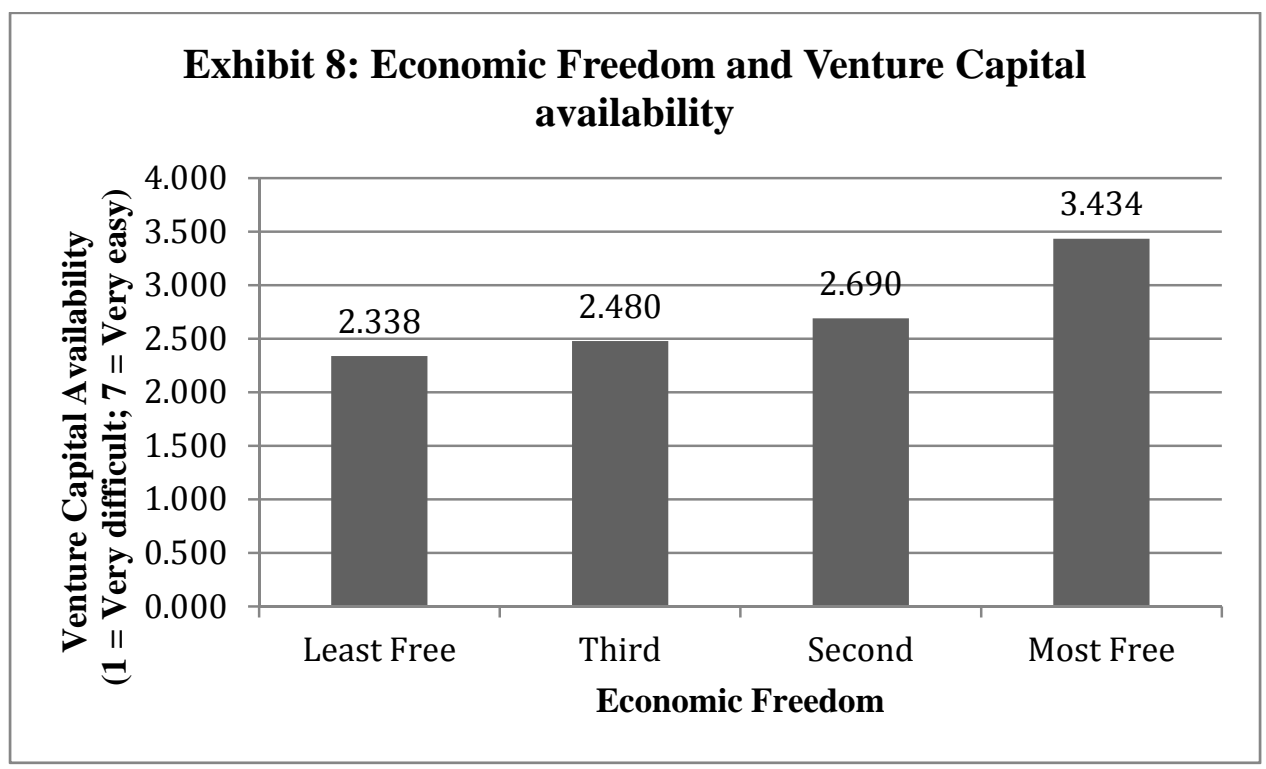

Sources: Fraser Institute, Economic Freedom of the World; World Economic Forum, Executive Opinion Survey.

Note: Based on the question: "In your country, how easy is it for entrepreneurs with innovative but risky projects to find venture capital? (1 = Very difficult; 7 = Very easy)” (Executive Opinion Survey). 


\section{References}

Al-Ubaydli, Omar, and Patrick McLaughlin. 2013. “RegData: A Numberical Database on Industry-Specific Regulations for All U.S. Industries and Federal Regulations, 19972010.” George Mason University Mercatus Center Working Paper No. 12-20.

Benson, Bruce. 2004. “Opportunities Forgone: The Unmeasurable Costs of Regulation.” Journal of Private Enterprise 19(2): 1-25.

Bindas, Michael. 2010. L.A. vs. Small Business: City of Angels No Heaven for Entrepreneurs. Institute for Justice City Study Series.

Bjørnskov, Christian, and Nicolai J. Foss. 2008. "Economic Freedom and Entrepreneurial Activity: Some Cross-Country Evidence.” Public Choice 134(3-4): 307-328.

Bjørnskov, Christian, and Nicolai Foss. 2012. How Institutions of Liberty Promote Entrepreneurship and Growth. In James Gwartney, Robert Lawson, and Joshua Hall (eds.) Economic Freedom of the World: 2012 Annual Report (Vancouver: Fraser Institute/Economic Freedom Network).

Campbell, Noel, and Tammy M. Rogers. 2007. “Economic Freedom and Net Business Formation.” Cato Journal 27(1): 23-36.

Frommer, Robert. 2010. Washington, DC vs. Entrepreneurs: DC's Monumental Regulations Stifle Small Businesses. Institute for Justice City Study Series.

Gohmann, Stephan, Bradley Hobbs, and Myra McCrickard. 2008. "Economic Freedom and Service Industry Growth in the United States.” Entrepreneurship Theory and Practice 32(5): 855-874.

Gohmann, Stephan, Bradley Hobbs, and Myra McCrickard. 2013. "Economic Freedom, Entrepreneurial Activity, and the Service Sector.” Journal of Entrepreneurship and Public Policy 2(2): 144-159.

Gwartney, James, Robert Lawson, and Walter Block. 1996. Economic Freedom of the World: 1975-1995 (Vancouver: Fraser Institute/Economic Freedom Network).

Gwartney, James, Robert Lawson, and Joshua Hall. 2014. Economic Freedom of the World: 2014 Annual Report (Vancouver: Fraser Institute/Economic Freedom Network).

Hall, Joshua, and Robert Lawson. 2014. "Economic Freedom of the World: An Accounting of the Literature.” Contemporary Economic Policy 32(1): 1-19.

Hall, Joshua C., and Justin M. Ross. 2009. "New Empirical Estimates of Rent-Seeking: An Update of Sobel and Garrett [2002].” Journal of Public Finance and Public Choice 27(23): 125-136. 
Hall, Joshua, and Russell Sobel. 2008. "Institutions, Entrepreneurship, and Regional Differences in Economic Growth.” American Journal of Entrepreneurship 1(1): 69-96.

Hall, Joshua, Boris Nikolaev, John Pulito and Ben VanMetre, 2013. "Freedom and Entrepreneurship: New Evidence from the States.” American Journal of Entrepreneurship 6(1): 85-99.

Holcombe, Randall. 2008. Entrepreneurship and Economic Growth. In Benjamin Powell (ed.) Making Poor Nations Rich: Entrepreneurship and the Process of Economic Development. (Stanford: Stanford University Press).

Hottot, Wesley. 2010. Houston, We Have a Problem: Space City Regulations Prevent Entrepreneurs from Taking Off. Institute for Justice City Study Series.

Kreft, Steven, and Russell Sobel. 2005. "Public Policy, Entrepreneurship, and Economic Freedom.” Cato Journal 25(3): 595-616.

Llosa, Alvaro Vargas (ed.). 2008. Lessons from the Poor: Triumph of the Entrepreneurial Spirit. Oakland, CA: Independent Institute.

Milnikel, Elizabeth, and Emily Satterthwaite. 2010. Regulatory Field: Home of Chicago Laws. Institute for Justice City Study Series.

Nyström, Kristina. 2008. "The Institutions of Economic Freedom and Entrepreneurship: Evidence from Panel Data.” Public Choice 136(3-4): 269-282.

Sanandaji, Tino, and Peter T. Leeson. 2013. "Billionaires.” Industrial and Corporate Change 22(1): 313-337.

Sobel, Russell S.. 2008. "Testing Baumol: Institutional Quality and the Productivity of Entrepreneurship.” Journal of Business Venturing 23(6): 641-655.

Sobel, Russell S., and Thomas A. Garrett. 2002. "On the Measurement of Rent Seeking and its Social Opportunity Cost.” Public Choice 112(1-2): 115-136.

Stansel, Dean. 2013. “An Economic Freedom Index for US Metropolitan Areas.” Journal of Regional Analysis and Policy 43(1): 3-20.

VanMetre, Benjamin J., and Joshua C. Hall. 2011. "How Friendly to Entrepreneurs are" Business Friendly" Policies? Some Preliminary Results.” Journal of Business and Economic Perspectives 37(1), 105-116.

Wiseman, Travis, and Andrew T. Young. 2013. "Economic Freedom, Entrepreneurship, and Income Levels: Some US State-level Empirics.” American Journal of Entrepreneurship 6(1): 100-119.

\section{Notes}


${ }^{1}$ For a discussion of the differences between Kizner and Schumpeter in this context see Holcombe (2008).

${ }^{2}$ Source: http://www.sba.gov/about-sba-services/what-we-do.

${ }^{3}$ Source: http://www.doingbusiness.org/data/exploretopics/trading-across-borders.

${ }^{4}$ Source: http://www.wto.org/english/res_e/booksp_e/tariff_profiles11_e.pdf.

${ }^{5}$ Sources: http://www.doingbusiness.org/data/exploretopics/dealing-with-construction-permits and http://www.doingbusiness.org/data/exploretopics/getting-electricity.

${ }^{6}$ The first edition of the EFW index was authored by Gwartney, Lawson and Block (1996). Much of this section is drawn, with permission from the publisher, from Chapter 1 of the EFW annual report (various years). Complete details on the EFW index are available at http://www.freetheworld.com.

${ }^{7}$ For a survey of the existing economic freedom-entrepreneurship literature see, Bjørnskov and Foss (2012). For an accounting of the literature that uses the Economic Freedom of the World index see Hall and Lawson (2014).

8 Perhaps this is why many so-called “pro-business” policies do not seem to related to measures of formal entrepreneurship in the United States (VanMetre and Hall 2011). 